\title{
Arteriovenous Fistula
}

National Cancer Institute

\section{Source}

National Cancer Institute. Arteriovenous Fistula. NCI Thesaurus. Code C36192.

An unintended connection between an artery and vein. 